\title{
The efficacy of Cognitive-Behavioral Therapy (CBT + TAU) on reducing type-I Bipolar disorder symptoms
}

\author{
Parviz Molavi $^{1}$, Habibeh Salvat ${ }^{2}$, Niko Salmani Aghdam ${ }^{3}$, Mehriar Nader Mohammadi ${ }^{4}$ \\ 1-Associate Professor, Department of Psychiatry, Ardabil University of Medical Sciences, Ardabil, Iran. \\ 2- Master of Clinical Psychology, Department of Psychiatry, Ardabil University of Medical Sciences, Ardabil, Iran. \\ 3- General Physician, Department of Psychiatry, Ardabil University of Medical Sciences, Ardabil, Iran. \\ 4- Assistant Professor, Department of Psychiatry, Ardabil University of Medical Sciences, Ardabil, Iran \\ (Corresponding Author). $\quad$ E-mail: mehriar46@yahoo.com
}

Received: $18 / 02 / 2020$

Accepted: 14/03/2020

\begin{abstract}
Introduction: Bipolar disorder is one of the most common psychiatric disorders. To treat and prevent the recurrence of the symptoms of this disorder, it is necessary to obtain information about treatment methods such as group cognitive-behavioral therapy with different techniques.

Aim: The aim of this study was to evaluate the efficacy of cognitive-behavioral therapy with the drug in reducing the signs and symptoms of bipolar type -I disorder.

Method: This is a pilot-experimental study (pre-test and post-test). The statistical population of this study was all patients with type-I bipolar disorder admitted to Ardabil Fatemi Hospital in 2018. In order to select the statistical sample, by using the available sampling method, 24 people from the mentioned population were selected (based on psychiatric diagnosis) and were replaced in two groups (experimental and control). SCID and Yang Mania scales were used to collect the data. Then, the data were entered into SPSS-21 software. For statistical analysis, Levn and covariance test were used.

Results: The results of statistical analysis showed that cognitive-behavioral therapy with drug had a significant effect on manic indicators and reduces its symptoms in patients with this disorder $(\mathrm{P}=0.05)$.

Conclusion: Cognitive-behavioral therapy can be used as a complementary therapeutic, along with pharmacotherapy, to reduce the signs and symptoms of type-I bipolar disorder. Also, according to the results of this study, the use of a team approach based on the cooperation of a psychologist and a psychiatrist in the treatment of mood disorders is recommended.
\end{abstract}

Keywords: Cognitive behavioral therapy, Drug therapy, Bipolar disorder-I

How to cite this article : Molavi P, Salvat H, Salmani Aghdam N, Nader Mohammadi M. The efficacy of Cognitive-Behavioral Therapy (CBT + TAU) on reducing type-I Bipolar disorder symptoms. Shenakht Journal of Psychology and Psychiatry. 2020; 7 (2): 92-103 .URL: http://shenakht.muk.ac.ir/article-1-656-fa.pdf

Copyright (C) 2018 the Author (s). Published by Kurdistan University of Medical Sciences. This is an open access article distributed under the terms of the Creative Commons Attribution-Non Commercial License 4.0 (CCBY-NC), where it is permissible to download, share, remix, transform, and buildup the work provided it is properly cited. The work cannot be used commercially without permission from the journal. 


\title{
اثربخشى درمان شناختى رفتارى همراه دارو در كاهش علائم و \\ I- نشانهاى اختلال خلقى دوقطبى نوع
}

\author{
يرويز مولوى'، حبيبه سلوت'، نيكو سلمانى اقدم"، مهريار ندرمحمدى ' \\ ا. ا.دانشيار، كروه روان يزشكى، دانشخاه علوم يزشكى اردبيل، اردبيل، ايران.

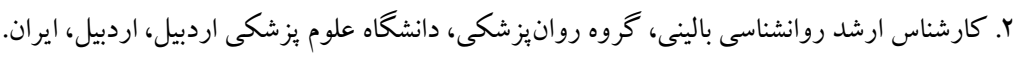

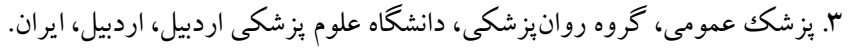

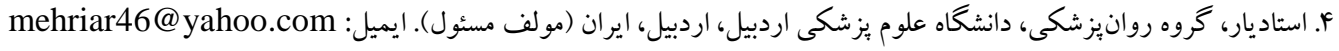

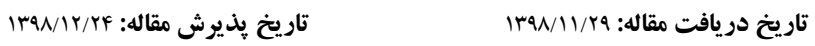

جكيده

مقدمه: اختلال دوقطبى يكى از شايعترين بيمارىهاى روانيزشكى است. براى درمان و جلو گيرى از عود علائم و نشانهاى اين

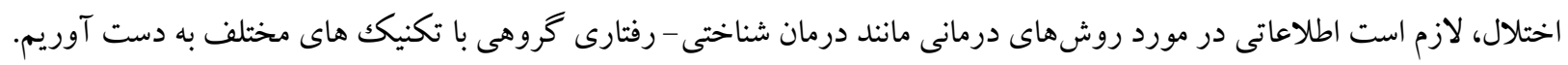
هدف: هدف از اين مطالعه بررسى اثربخشى درمان شناختى رفتارى همراه دارو در كاهش علائم و نشانهاى اختلال خلقى دو قطبى نوع -I است.

روش: اين يزوهش يكك مطالعه آزمايشى - تجربى (ييشآزمون و بس آزمون) است. جامعه آمارى بزوهش، كليه بيماران اختلال

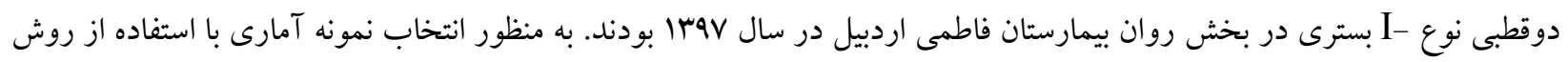
نمونه گيرى در دسترس تعداد بF نفر از جامعه مذكور انتخاب (بر اساس تشخيص روانيزشك) و دو در دو گروه (آزمايش و كنترل)

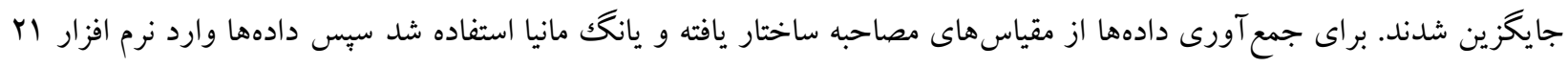
شده و جهت تجزيه و تحليل آمارى نيز از آزمون اون و كواريانس استفاده شد. SPSS

يافتها: نتايج حاصل از تحليل آمارى نشان داد، درمان شناختى - رفتارى همراه دارو تأثير معنادارى بر شاخص هاى مانيا داشته و موجب

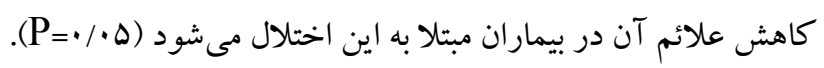
نتيجه كيرى: درمان شناختى رفتارى مى تواند به عنوان يك روش درمانى مكمل، همراه دارو درمانى در كاهش علائم و نشانهاى

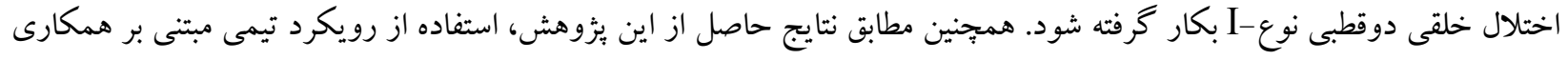
روانشناس و روانيزشك در درمان اختلال خلقى بيشنهاد مى شود. I- كليد وازهها: درمان شناختى رفتارى، دارو درمانى، اختلال دوقطبى نوع 
تجربه كنند (كلينمن "و همكاران، س..Y). وضعيت بد مقدمه اقتصادى، بيكارى، اخراج از كار، اختلاف در زندكى زناشويى، عدم ادامه تحصيل و هم جنين بسترىهاى متعدد در مراكز روان يزشكى، از عوارض اين اختلال

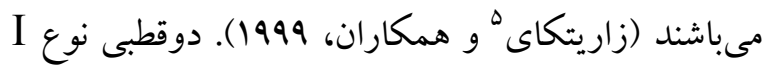
را مىتوان بـا يكك برنامـه درمانى منظم و با استفاده از داروها و روان درمانى كنترل نمود. در صورت عدم درمان مناسب ميزان عود افزايش مىيابد. تاكنون داروهاى مختلفى به عنوان تثبيت كنندهى خلق معرفى شدهاند. ليتيوم يكى از ير مصرفترين داروها در درمان

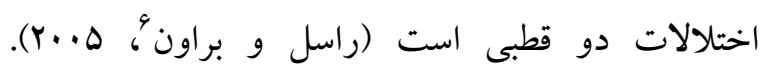
كاربامازيين و واليروات از دهلى • لو اله بعد در درمان اين اختلال وارد شدند كه علاوه بر لتيم از داروهاى رايج در درمان اين اختلال مىباشند (قريشىزاده و فرخى، (Y...

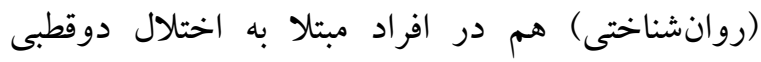
استفاده مىشود. يكى از اين نوع درمان، رواندرمانى شناختى -رفتارى است. در شيوههاى شناختى - رفتارى، نكرهاى ناكارآمد، از طريق تكنيكهاى خاص، مورد بازسازى قرار مى گيرند؛ بدين صورت كه درمانكر، در

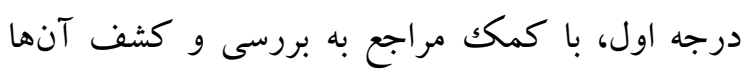

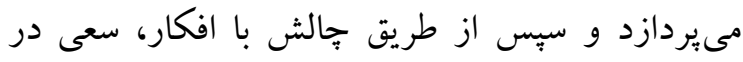
تغيير آنها دارد؛ از سوى ديخر، مراجع نيز ترغيب مىشوند تا افكار خود را شناسايى كرده و به رد آنها بيردازند. درمان شناختى -رفتارى، بيماران را به حل

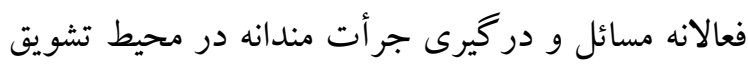
و بر توانايى فرد جهت تفسير و تغيير مناسب رويدادها

4- Kleinman

5 - Zaretsky

${ }^{6}$ - Russel \& Browne

1 - Muray

${ }^{2}$ - Salvatore

3. Goodwin 
رفتار درمانگرى به تنهايى يا به صورت تركيبى با دارودرمانى نسبت به دارو درمانى به تنهايى، درمان كارآمدترى براى اختلالات دوقطبى است و نه تنها مى تواند ناراحتىهاى حاد را كاهش داده و درمان كند،

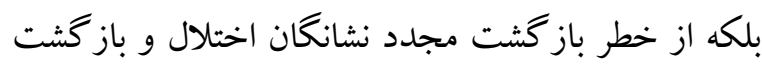
بيمارى در طولانى مدت و پِ از قطع دارو جلو گيرى

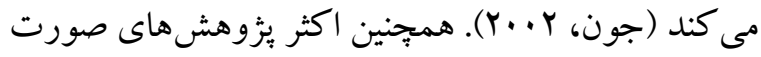
كرفته در اين زمينه متمركز بر بررسى كارايى فنون شناختى -رفتارى در درمان افسردگى يكك قطبى بوده و تعداد كمى از مطالعات به ارزيابى سودمندى و اثربخشى

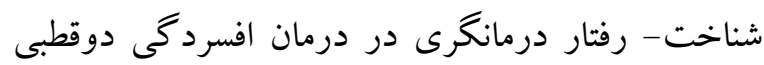
يرداختهاند و علاوه بر مطالب فوق الذكر، جون تأثيرات مداخلات روانى بر روى اختلال دو قطبى در ايران كمتر مورد مطالعه قرار كرفته است (هو كسلى و و همكاران، . .... شناختى- رفتارى در درمان اختلال روانى و ضرورت درمان روان شناختى مكمل در كنار درمان دارويى، در يثزوهش حاضر به مقايسهى اثربخشى درمان شناختى رفتارى همراه دارو در كاهش علائم و نشانهاى اختلال خلقى دوقطبى نوع I در بيماران بسترى در بخش روان بيمارستان فاطمى اردبيل برداخته شده است.

روش

اين بزوهش يك ولى مطالعه آزمايشى - تجربى (كروه آزمايشى و كنترل با بيش آزمون و يس آزمون) (كار آزمايى بالينى) است. در اين تحقيق جامعه يزوهش، كليه بيماران اختلال دوقطبى بسترى در بخش روان بيمارستان فاطمى اردبيل در سال VQII بودند. به منظور انتخاب

6. Huxley
تأكيد مىنمايد (هو كارتى' و همكاران، 9. . ب). نتيجه مطالعه قادرى و همكاران (قادرى و همكاران، 19 (Y) نشان دهنده اين است كه درمان شناختى - رفتارى به عنوان يك درمان روانشناختى مكمل با دارو درمانى بيماران دوقطبى مىتواند در كاهش علائم و اصلاح نكرشهاى ناكار آمد اين بيماران مؤثر باشد. نتيجه مطالعه

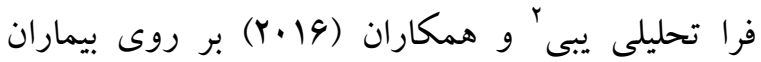
دوقطبى نشان داد درمان شناختى - رفتارى در كاهش عود اختلال دوقطبى نوع I در بيخيرى 9 ماهه مؤثر بوده و در بهبودى شدت مانيا تأثير داشته است. اگرجهه شناخت و دانش ما دربار هُ اختلال افسردگى -مانيا رو به افزايش است؛ اما بُزوهش در زمينه درمان اختلال دو قطبى بسيار محدود است. به علاوه، هر جند كه

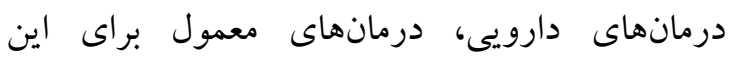

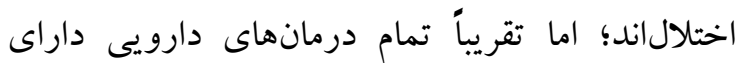

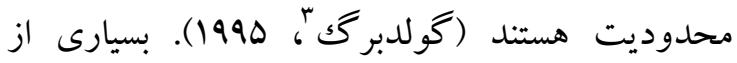
بيماران مبتلا به اختلال افسردگى دوقطبى نسبت به ليتيوم و ساير داروها مقاوماند و برخى نمىتواند اثرات جانبى

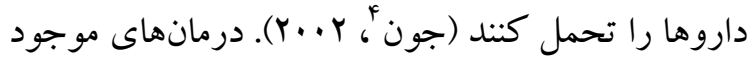
موجود به خوبى قادر به كنترل علائم بيمارى نمىباشند

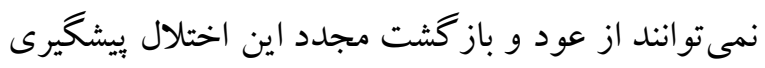

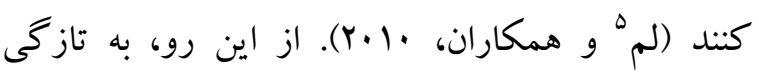
يثزوهشخران و متخصصان بالينى براى درمان اختلال دو قطبى به رويكردهاى مختلف روان درمانكرى از جمله

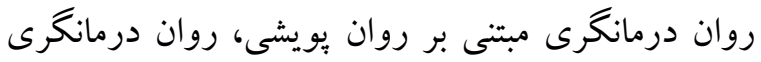
بين فردى و شناخت ـ رفتار درمانكرى علاقهمند شدهاند. از دگرسو، نتايج يزوهشها نشان داده است كه شناخت

\footnotetext{
1. Hogary

2- Yeby

3 - Goldberg

${ }^{4}$ - John

5. Lam
} 
درمان دارويى و به مدت ^ هفته درمان شناختى - رفتارى بر اساس روش جى سى رايت دريافت كردند. اجراى درمان شناختى -رفتارى توسط روانشناس صورت گرفت. همجنين در هر دو گروه ميزان و نوع داروى مصرفى بر

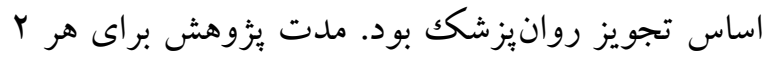
كروه r ماه بود. در حين اجراى مداخلات هر دو هفته يككبار بيماران از نظر شدت بيمارى و علائم نشانهاى اختلال دو قطبى نوع يكك مورد ارزيابى قرار كرفت. سبِ بعد اتمام مداخلات برسشنامههاى بُزوهشى مجدداً

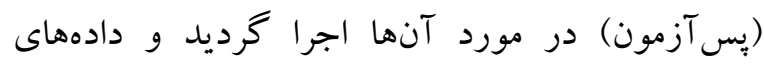
كردآورى شده مورد تجزيه و تحليل قرار گرفت. جهت تجزيه و تحليل دادهها نيز از آمار توصيفى شامل؛ ميانگين و انحراف معيار استفاده شد و به منظور تجزيه و تحليل فرضيه هاى يزوهش نيز از آزمون لون و كواريانس استفاده شد. در اين يثوهش از روان درمانى شناختى رفتارى استفاده شد. اين يروتكل شامل ^ جلسه درمانى يك ساعته به مدت Y ماه بود كه محتواى آن بهطور خلاصه در جدول شماره ا آمده است.
نمونه آمارى با استفاده از روش نمونه گيرى در دسترس تعداد YF نفر از جامعه مذكور انتخاب (بر اساس تشخيص روان بزشك) و در دو گروه، گروه درمان دارويى (r) نفر) و گروه درمان شناختى رفتارى همراه دارو (Y ( نفر) جايگزين شدند. شايان ذكر است قبل از انتخاب نمونه آمارى معيار ورود و خروج افراد به گرووهها بدين شكل طراحى شد؛ معيارهاى ورود افر اد عبارت بودند از؛ داشتن سن حداقل 11 سال و حداكثر •ه سال، تجربه اولين اييزود بيمارى و عدم همبودى با اختلالات سايكوتيكك و اعلام رضايت كتبى. معيارهاى خروج نيز عبارت بودند از؛ داشتن سوءمصرف مواد و الكل، باردار بودن بيماران زن، داشتن اختلالات عصب شناختى. براى جمع آورى دادهاى مورد نياز از مقياسهاى مصاحبه ساختار يافته

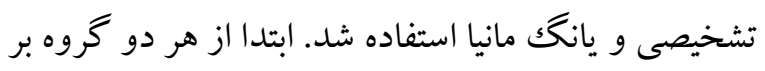
اساس يرسشنامهاى مذكور بيش آزمون به عمل آمد.

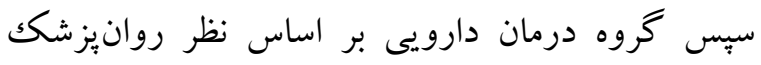
درمان دارويى را دريافت كردند و بيماران گرووه درمان شناختى رفتارى همراه دارو بر اساس نظر روانيزشك

جدول ا ساختار و محتواى جلسات مداخله به شيوهى شناختى - رفتارى

\begin{tabular}{|c|c|}
\hline محتواى جلسات & جلسه \\
\hline اطلاعات كلى برنامه؛ توضيح در مورد ساختار برنامه و آشنايى با نحوهى كار & اول اول \\
\hline آموزش در مورد بيمارى (علائم، سبب، سير و درمان) شناسايى و ييشگيرى از عود & دوم \\
\hline درمان دارويى(مديريت درمان و راهبردهاى افزايش يذيرش آن) & 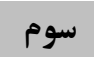 \\
\hline مديريت سبكك زندگى (كنترل رفتارهاى برانگيزاندهى عود و افزايش رفتارهاى مثبت در سبك زندگى) & جهارم \\
\hline مديريت رفتارهاى منفى (كاهش فعاليتهاى بسيار برانگيزان & ينجم \\
\hline مداخلات شناختى(شناخت باورها و افكار خود كار منفى و ارتباط آن با احساسات و رفتارها) & ششم \\
\hline مداخلات شناختى (اصلاح افكار تحريفشده و ناكار آمد و اصلاح باورهاى مرتبط با بيمارى كه بر عزت نفس تأثير مى گذارند) & هفتم \\
\hline كنترل خشم و حل مسئله؛ مديريت استرس و كنترل هيجانات، حل مسئله و تعارض در مشكلات بين فردى & 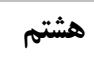 \\
\hline
\end{tabular}

مصاحبه ساختار يافته (DSM-IV(SCID) : يك مصاحبه

نيمه ساختار يافته است كه تشخيصهايى براساس سلك 
Gold تشخيصهاى ارائه شده توسط روانيز شكان را Standard حساسيت بوده است. در اكثر تشخيصها ويز گى، بالاتر از هم/· و در نيمى از اين تعداد بالاى 9/، بود كه نشان

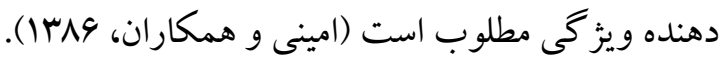
برسشنامهى معيار مانيا' (YMRSS): مقياس يانك يازده آيتم دارد كه براى مشخص ساختن نشانهاى اختلال

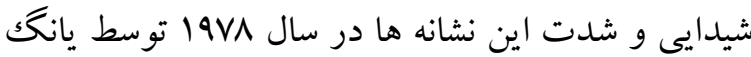

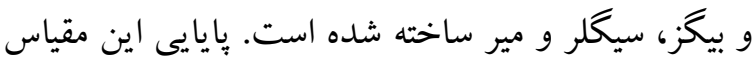
از همسانى درونى بهوسيله مقايسه نمرات دو آزمايشخر مستقل طى مصاحبه مشتر كك به دست آمده، همبستخى بـى كلى 99/ و حداقل همبستخى آن 199· بود (يانك و

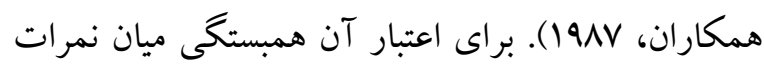
اين مقياس با مقياس شيدايى كلوبال، مقياس شيدايى بيكل و مقياس بترسون مورد ارزيابى قرار گرفت كه حاكى از باز

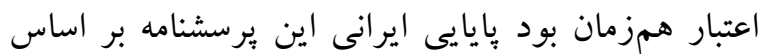

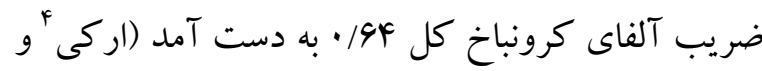

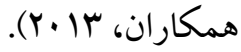

يافتهها از بين بيماران شركت كننده در اين بثزوهش 99/V درصد

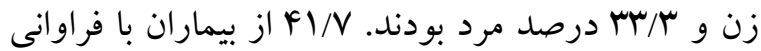
بيشتر تحصيلات راهنمايى، س/س تحصيلات دانشگاهى و

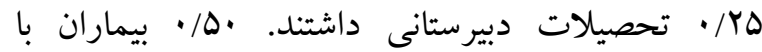

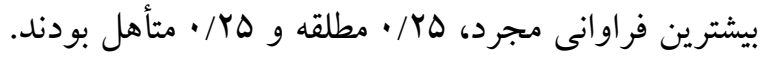
1VD · درصد بيماران سابقه بيمارى بسترى در بخش روان را داشتند ولى ه广/ • درصد بار اولى بود كه در بيمارستان روانيزشكى بسترى مى شدند. همجنين به گفته خودشان،

3. Young Mania Rating Scale.

4- Arky
راهنماى تشخيصى و آمارى اختلالات روانى فراهم مى آورد. اجراى آن نيازمند قضاوت بالينى مصاحبه كر در المر مورد باسخ هاى مصاحبه شونده است و به همين دليل مصاحبه كر بايد واجد دانش و تجربه بالينى در زمينه آسيب شناسى روان باشد. يكى از اهداف سازندكان اين

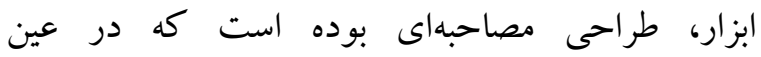
ساختاريافتكى، استفاده از آن براى متخصصان بالينى ساده باشد (اسييزر' و همكاران، 1991). روايى مصاحبه ساختاريافته با تشخيص بالينى روانيز شكان داراى دانشنامه تخصصى روانيزشكى سنجيده شده است. تشخيص هر بيمار به صورت توافق دو روانيزشك و بر اساس كل اطلاعات موجود داده شد و براى اين منظور از خكك ليست معيارهاى تشخيصى بر اساس راهنماى تشخيصى و آمارى اختلالات روانى استفاده شد كه توسط امينى

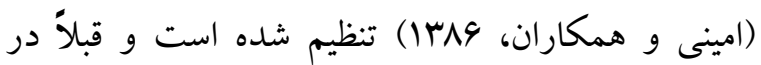
مطالعهاى ديخر (امينى و همكاران، ولىז) به كار خرفته

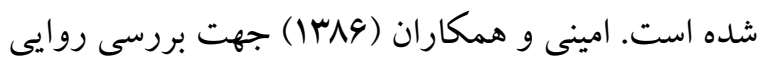
با هر بيمار يك مصاحبه كامل با استفاده از مصاحبه ساختاريافته توسط برسشخر آموزش ديده انجام دادند. آنكاه براى سنجش روايى مصاحبه ساختاريافته ظرف ب

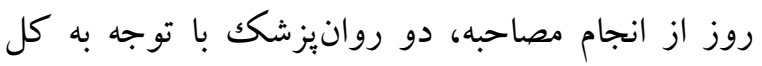
اطلاعات موجود، با جکك ليست راهنماى تشخيصى و

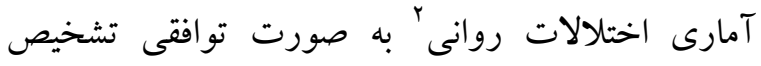
كذارى كردند و نتايج با تشخيصهاى مصاحبه

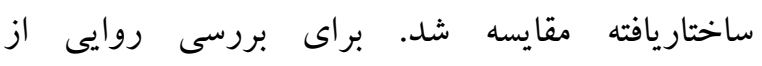
شاخصهاى كايا، درصد توافق تشخيصى، حساسيت و ويزگى استفاده شد. براى تمام تشخيصها جز كل

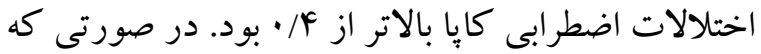

\footnotetext{
1- Spitzer

${ }^{2}$ - Diagnastic and Statistical Manual of mental disordes
} 
دادههاى توصيفى شامل ميانگين و انحراف استاندارد مرتبط به هر دو گروه در جدول شماره Y نمايش داده شده است و توضيحات مربوط به هر كدام در زير جدول آمده است.
از لحاظ وضعيت اقتصادى، ·له درصد از بيماران وضعيت اقتصادى متوسطى داشتند، 19/V درصد وضعيت اقتصادى خوب، م/N درصد وضعيت اقتصادى عالى، 19/N درصد وضعيت اقتصادى بد و م/ درصد وضعيت اقتصادى

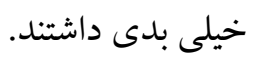

\begin{tabular}{|c|c|c|}
\hline كنترل & آزمايش & \\
\hline Y/YYIMT/FG & $r / \cdots \pm \uparrow q / . \cdot$ & ييش آزمون \\
\hline$r / \Lambda r \pm r \Delta / r r$ & $1 / 19 \pm 1 / / \Delta$ & پس آزمون \\
\hline
\end{tabular}

نشان دهنده رضايت بخش بودن روان درمانى شناختى رفتارى در كروه آزمايش مىباشد.قبل از استفاده از آزمون پيارامتريكك تحليل كواريانس جهت رون رعايت فرضهاى آن، از آزمون لون (جدول ب) استفاده شد.
جدول شماره r نشان دهنده وضعيت گروه آزمايش و كنترل قبل و بعد از مداخلات (كروه آزمايش؛

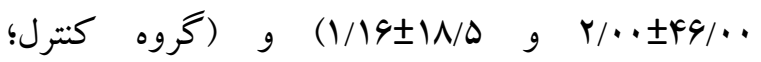
(

\begin{tabular}{|c|c|c|c|c|}
\hline \multicolumn{5}{|c|}{ جدول ஈ آزمون لون جهت بررسى همكنى واريانسها } \\
\hline سطح معنادارى & درجه آزادى ب & درجه آزادى 1 & F توزيع F & \\
\hline $1 . \mathrm{rq}$ & rr & 1 & D/FYY & 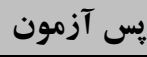 \\
\hline
\end{tabular}

$$
\text { بر به درستى رعاست آزمون لون شرط همخنى ماتريس هاى كواريانس }
$$

\begin{tabular}{|c|c|c|c|c|c|c|c|}
\hline آمارى & ضريب اتا & معنى دارى & $\mathbf{F}$ & مجانكين & آزادى درجه & مجذوروات & منبع \\
\hline /9VF & /FFF & $\cdot / \cdot .1$ & $19 / 1 .$. & $r / 99 \mathrm{~V}$ & 1 & r/gWV & خلق بالا \\
\hline $1 / \cdots$ & 1940 & $1 \cdots$ & rN/IIT & $r / 9 \wedge 9$ & 1 & $r / 9 \wedge 9$ & فعاليت حر كتى \\
\hline IADr & $119 \mathrm{~V}$ & 1.MF & $\Delta / 19$ & 199. & 1 & 199. & علايق جنسى \\
\hline 1994 & $10 \cdot$. & $1 \cdots$ & $r r / \cdots$ & $r / 99 \mathrm{~V}$ & 1 & r/99V & خواب \\
\hline /99r & $10 \cdot 1$ & $1 \cdots$ & $r / 991$ & $r / A \Delta V$ & 1 & $r / \Lambda \Delta V$ & تحريك بذيرى \\
\hline /rav & ITI & 1.9. & $r / 199$ & $1 / .4 r$ & 1 & $1 / \cdot k r$ & سرعت و مقدار كفتار \\
\hline $1 A \cdot \Delta$ & IYAF & $1 \cdots 1$ & $\Lambda / V r \Lambda$ & $1 / \pi V 9$ & 1 & $1 /$ rVG & اختلال در زبان \\
\hline 1919 & /YII & I.TV & $\Delta / 9 Y 9$ & $F / \mu l$. & 1 & $F / T)$. & محتواى فكر \\
\hline
\end{tabular}




\begin{tabular}{|c|c|c|c|c|c|c|c|}
\hline lQFF & $/ r 9 \Lambda$ & $1 \cdots 1$ & Ir/A9F & $\Delta / \cdot F r$ & 1 & $\Delta / \cdot F r$ & رفتار برخاشكر انه \\
\hline 1.90 & $1 \cdots v$ & $/ V \cdot \Lambda$ & IFF & $11 \cdot V$ & 1 & $11 \cdot V$ & ظاهر و قيافه \\
\hline IArq & $10 \ldots$ & 10.9 & $Q / \Delta Q V$ & $F / 19 \mathrm{~V}$ & 1 & $F / 19 V$ & بينش \\
\hline$\mu$ & $1 \cdot 19$ & 1149 & Y/YAY & $1 . / 194$ & 1 & $1 . / 194$ & ييش آزمون(كل) \\
\hline \multirow[t]{2}{*}{$1 / \cdots$} & NAF & $/ \cdots$ & $9 \cdot 1 \Delta \Delta q$ & rqq/949 & 1 & rqQ/9FI & كروه(كل) \\
\hline & & & & $F / f \Delta r$ & 1 & $Q 9 / 0 \cdot r$ & خطا \\
\hline
\end{tabular}

تبعيت از درمان دارويى و بهبود عملكرد بين فردى بيماران مبتلا به اختلال دو قطبى يكك مؤثر باشد. همجينين نتايج مطالعهاى طالبى نشان داد كه روش درمان شناختى مبتنى بر ذهن آكاهى، موجب كاهش شدت علائم

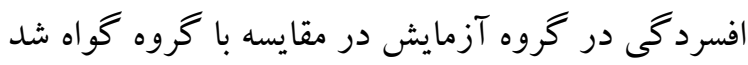
؛اما جنين كاهشى در شدت علائم شيدايى مشاهده نشد

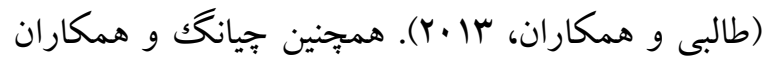
در نتايج يكك فرا تحليلى گزارش كردند كه درمان شناختى - رفتارى در كاهش ميزان عود و بهبود علائم افسردگى، شدت مانيا و عملكرد روانى -اجتماعى با اثرات خفيف تا متوسط مؤثر است (جيانگ و همكاران، Y. IV). نتايج مطالعه ديخرى نشان داد كه درمان شناختى - رفتارى به عنوان يكك درمان روانشناختى مكمل با دارو درمانى بيماران دوقطبى مىتواند در كاهش علائم و اصلاح نكرشهاى ناكارآمد اين بيماران مؤثر باشد (قادرى و همكاران، 19 (Y). يبى و همكاران در سال 19 19 در نتايج يكك فرا تحليلى گز ارش دادند كه روان درمانى شناختى رفتارى در كاهش عود اختلال دوقطبى در بييگيرى 4 ماهد و بهبودى شدت مانيا بر اساس مقياس مانياى يانگك تأثير

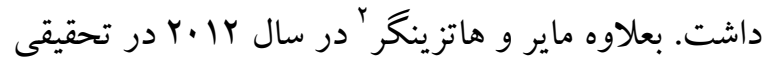
نشان داد هر دو درمان درمان شناختى - رفتارى و درمان حمايتى تأثير معنادارى بر كاهش علائم افسردگى و بهبود

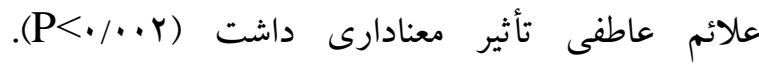

${ }^{2}$ - Meyer \& Hautzinger
نتايج جدول f أشان مىدهد كه تفاوت معنادارى (P=•/・ه) دارد؛ يعنى درمان شناختى رفتارى همراه دارو باعث كاهش علائم و نشانهاى اختلال دوقطبى نوع- I در بيمار ان مبتلا به اين اختلال شده است. هدف از اجراى يثوهش حاضر، بررسى اثربخشى درمان شناختى - رفتارى همراه دارو در كاهش علائم و نشانهاى اختلال دوقطبى نوع-I بود. بر اساس نتايج به دست آمده، درمان شناختى - رفتارى همراه دارو تأثير معنادارى بر شاخصهاى مانيا داشته و موجب كاهش علائم آن در بيماران شد (ه=/P)

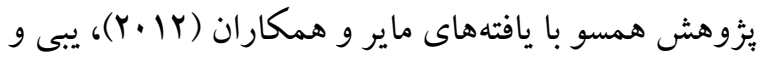

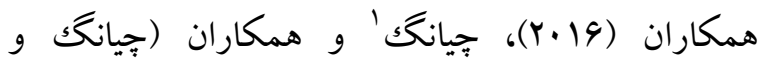

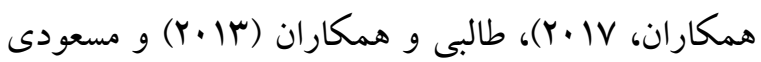
(Y.人) (ץ. ) است.

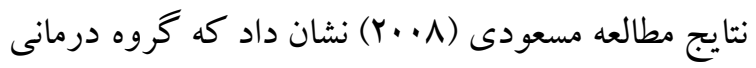
شناختى - رفتارى توأم با مصرف دارو به طور معنادارى نسبت به دارودرمانى در افزايش تبعيت از درمان دارويى لهي

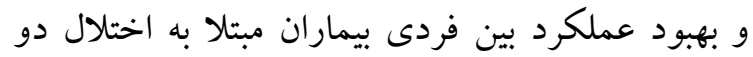
قطبى يكك مؤثر بوده است و درمانى شناختى رفتارى به عنوان يكك رويكرد درمانى مكمل مىتواند در افزايش 
به علائم خرده نشانه اى موجود و علائم همراه ضرورى

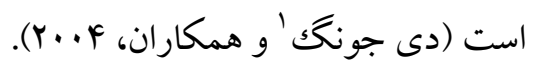

همجنين مى توان كَت، اغلب درمانهاى دو قطبى براى برطرف كردن مرحله حاد اختلال هستند. گر جهه استفاده از دارو، به خصوص در درمان مرحله حاد، مزاياى درمانى قابل توجهى به وجود مى آورد، درصد عمدهاى از بيماران داراى اختلال دوقطبى، با وجود استفاده از تثبيت كنندههاى خلقى، هنوز عود بيمارى را تجربه مى كنند. يايبندى دارويى پايين، وجود علائم خرده نشانه افسردگى و مانيا، مهارتهاى مقابلهاى ضعيف در رياسخ به علائم اوليه و هشدار دهنده و آشفتكى در خواب و روالهاى روزمره خطر عود را بالا مىبرد؛ بر اساس مطالعات انواع مختلف درمانهاى روانشناختى نيز براى اختلال وجود دارند. كرجه تا كنون ثابت نشده كدام نوع درمان، بهترين و كاراترين است، استفاده از هر يكك از اين درمانها مىتواند راهى براى بهبود بيمارى باشد (راشدى و

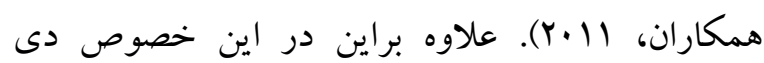
جونگك و همكاران عنوان نمود كه هر دو اين روشها، داراى كارآمدى لازم در درمان مشكلات اختلال مانيا را دارا مىباشند و آن جه بيش از نوع درمان اهميت دارد،

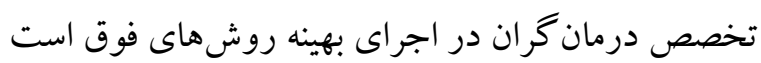
(دى جونگ اين درمانها نقاط مشتركى دارند، بيمارانى كه براى انطباق با بيمارى، يايبندى به برنامه دارويى، شناسايى و مديريت علائم اوليه و علائم هشدار دهنده اختلال و شناسايى استرسزاهاى محيطى به كمكك نيازمندند، همه به نوعى از اين درمانها بهر ممند خو اهند شد.
همجنين بيان كردند كه ويثز گهاى مشتر ك خاص (مثلاً اطلاعات، حالتهاى خلقى) ممكن است اثرات درمان روانشناختى براى دو قطبى را توضيح دهد (ماير و

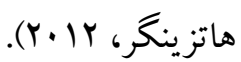
درمان شناختى رفتارى با آموزش بيماران در خصوص بيمارى و علائم اوليه مانيا، توجه به روالهاى روزمره از جمله خواب و آموزش مهارتهاى مقابله اى براى برطرف كردن علائم باقى مانده و خرده نشانه افسردگى و مانيا به كاهش خطر عود كمك مى كند. شايد يكى با ارزشترين جنبههاى درمان شناختى رفتارى توانايى آن در كاهش علائم خرده نشانه باشد. در اين يثوهش اين درمان در كاهش علائم، موفق عمل كرد و در علائم مانيا كاهش معنادارى به دست آمد؛ درمان همجِنين به دليل آشنا كردن بيمار با ماهيت بيمارى و آموزش روش هايى غير دارويى براى كنترل علائم، در بهبود عزت نفس بيماران اثر دارد. روشهاى رفتارى كنترل محيط براى مديريت زندكى بيماران بعد از اتمام جلسات كمكك كننده است. درمان شناختى رفتارى، درمانى بيمار محور است كه به بيمار كمك مى كند تا در روند بيمارى، كنترل علائم و بهبود خود نقش داشته باشد؛ همين، امر

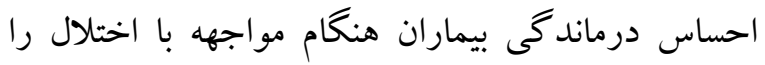
كاهش مىدهد. بهبود كاركردى از آن جهت با اهميت است كه بعد از سبرى شدن مرحله حاد بيمارى، باعث برقرارى ارتباط و تماس مجدد فرد بيمار با محيط اجتماعى بيرامونش مىشود؛ يس به اندازه بهبود علامتى مهم است و بايد توجهى ويثه به اين امر مبذول شود؛ در نهايت اينكه درمان بايد از بهبود علامتى به سمت بهبود كاركردى سوق داده شود. براى بهبود كاركردى، توجه

\footnotetext{
1- De Jonghe
} 


\section{References}

Amini H, Alaghbandandrad j, Shahrivar Z, Davari Ashtiani R, Arab Fariba, Hakim Shoshtari M. (2007). Narrative of the Persian version of the Comprehensive International Diagnostic Interview (CIDI) for the diagnosis of schizophrenia and bipolar disorder. [In Persian]

Amini H, Sharifi V, Asadi SM, Mohammadi MR, Kaviani H, Semnani Y, Siddiq A. (2007). Narrative of the Persian version of the Structured Diagnostic Interview for Axis I Disorders in (SCID-I) (DSM-IV). [In Persian]

Angst J. (1998). The emerging epidemiology of hypomania and bipolar II disorder. Journal of affective disorders, 50(2-3), pp.143-151.

Arki M, Abasi Esfajir AA, Naderi H.(2013). Determination the efficacy of cognitivebehavior therapy group with role-playing in patients with bipolar disorder. Joumal of North Khorasan University of Medical Sciences, 5(3), pp.527-548.

Chiang KJ, Tsai JC, Liu D, Lin CH, Chiu HL, Chou KR. (2017). Efficacy of cognitive-behavioral therapy in patients with bipolar disorder. A meta-analysis of randomized controlled trials. PloS one, 12(5).

De Jonghe F, Hendricksen M, Van Aalst G, Kool S, Peen V, Van R, Van Den Eijnden E, Dekker J. (2004). Psychotherapy alone and combined with pharmacotherapy in the treatment of depression. The British Journal of Psychiatry, 185(1), pp.37-45.

Ghaderi D, Maroufi M, Ebrahimi A. (2016). Effect of cognitive behavioral therapy on reducing symptoms and modifying dysfunctional attitudes in patients with type I and II bipolar disorder. Joumal of Isfahan Medical School, 33(358), pp.1936-1942. [In Persian]

Ghoreishizadeh SM, Fakhari A. (2000). Comparison of effects of lithium, carbamazepine and valproate in treatment of acute phase of classic mania. Journal Andeeshe va Raftar, 4(4), pp.4 9. [n Persian]

\section{نتيجه كيرى}

يافته هاى بزٔوهش حاضر مؤيد اين نكته است كه روان درمانى شناختى -رفتارى در كنار درمانهاى معمول، در كاهش علائم و نشانهاى اختلال خلقى دوقطبى نوع يكى در بيماران بسترى تأثير معنادارى داشته، لذا مىتوان از اين نوع درمان در بيماران مبتلا به اين اختلال استفاده كرد. همجِنين بر اساس نتايج حاصل از اين بُزوهش، استفاده از رويكرد تيمى مبتنى بر همكارى روان شناس و روان

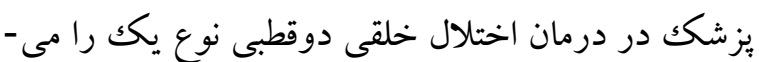
تواند نتايجى درمانى بهترى را نشان دهد. از محدوديت هايى كه مىتواند براى يُزوهش حاضر مطرح باشد عبارتاند از: زمان بسترى اين بيماران اشاره نمود كه حداكثر زمان نگگهدارى در بخش از روز اول بسترى، .ب روز است كه حداقل زمان براى رسيدن به تثبيت فاز حاد بين يكك تا دو هفته متغير است و در اين بين، بعضى از بيماران با نظر يزشك معالج يا با رضايت شخصى خانواده، در بين طرح، ترخيص مىشدند و اين باعث ريزش نمونها مىشد همجنين بعد از ترخيص، همكارى نمونهها به حداقل مىرسيد. از محدوديتهاى ديخر يُزوهش مىتوان به كوتاه بودن دورهى مداخله و عدم

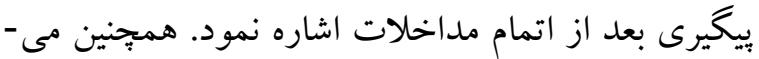

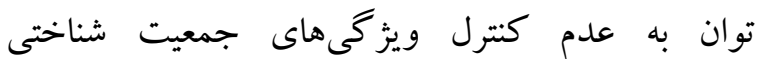
خروههاى مورد مطالعه و محدود بودن نمونه به شهر اردبيل اشاره كرد كه مى تواند نتايج به دست آمده را تحت تاثير قرار دهد.

\section{سياسگز ارى}

بدينوسيله از همكارى صميمانه كليه افرادى كه در اين يثزوهش ما را يارى كردند تشكر و قدردانى مىشود. 
Goldberg. (1995). Course and outcome in bipolar affective disorder: a longitudinal follow-up study. The American joumal of psychiatry.

Goodwin GM, Haddad PM, Ferrier IN, Aronson JK, Bames T, Cipriani A, Coghill DR, Fazel S, Geddes JR, Gunze H, Holmes EA. Macmillan IC. McAllister-Williams $\mathrm{H}$, Miklowitz DR, Moriss R, Munafô M, Paton C, Saharkian BJ, Saunders K, Sinclair J, Taylor D, Vieta E, Young AH. (2016). Evidence-based guidelines for treating bipolar disorder: revised third edition recommendations from the British Association for Psychopharmacology. J Psychopharmacol, 30, 495-553.

Hogarty GE, Greenwald DP, Eack SM. (2006). A memorial tribute: Durability and mechanism of effects of cognitive enhancement therapy. Psychiatric Services, 57(12), pp.1751-1757.

Huxley NA, Parikh SV, Baldessarini RJ, Huxley NA, Parikh SV, Baldessarini RJ. (2000). Effectiveness of psychosocial treatments in bipolar disorder: state of the evidence. Harvard Review of Psychiatry, 8(3), pp.126-140.

Jannati Sh, Farid H, Kashani A, Seifi H. (2017). The effectiveness of cognitive-behavioral group therapy on depression, anxiety and self-esteem in patients with type 1 bipolar disorder. Joumal of Mental Health Principles, 19 (2), 113-118. [In Persian]

John C. (2002). Cognitive Therapy for Bipolar Disorder: A Therapist's Guide to Concepts, Methods and Practice-DH Lam, SH Jones, P. Hayward and J. Bright; Wiley, Chichester, 1999, x+ 308 pp., Price@ \$19.99. Behaviour Research and Therapy, 3(40), p.343.

Kleinman LS, Lowin A, Flood E, Gandhi G, Edgell E, Revicki DA. (2003). Costs of bipolar disorder. Pharmacoeconomics, 21(9), pp.601-622.

Lam DH, Jones SH, Hayward P. (2010). Cognitive therapy for bipolar disorder. A therapist's guide to concepts, methods and practice (Vol. 101). John Wiley \& Sons.

Masodi SH. (2008). The effect of cognitive-behavioral group therapy on the outcome of type 1 bipolar disorder. Joumal of Mental Health

Principles, 10 (40), 289-298. [In Persian]

Meyer TD, Hautzinger M. (2012). Cognitive behaviour therapy and supportive therapy for bipolar disorders: relapse rates for treatment period and 2-year follow-up. Psychological medicine, 42(7), pp.1429-1439.

Murray CJ, Lopez AD. (1996). Evidence-based health policy-lessons from the Global Burden of Disease Study. Science, 274(5288), 740-743.

Rashedi E, Sohrabi F, Shams J. (2011). The effectiveness of cognitive-behavioral therapy in preventing recumence of bipolar disorder. Joumal of Clinical Psychology and Personality, 2 (5), 49-64 .[In Persian]

Russell SJ, Browne JL. (2005). Staying well with bipolar disorder. Australian \& New Zealand Joumal of Psychiatry, 39(3), pp.187-193.

Salvatore P, Tohen M, Khalsa HMK, Baethge C, Tondo L, Baldessarini RJ. (2007). Longitudinal research on bipolar disorders. Epidemiology and Psychiatric Sciences, 16(2), pp.109-117.

Shabani A, Teimurinejad S, Kokar S, Asl MA, Shariati B, Behbahani ZM, Ghasemzadeh, MR, Hasani S, Taban M, Shirekhoda S, Ghorbani $\mathrm{Z}$ (2017). Suicide risk factors in Iranian patients with bipolar disorder. a 21-month follow-up from BDPF study. Iranian joumal of psychiatry and behavioral sciences, 7(1), p.16. [In Persian]

Shirazi E, Shabani A, Hakim Shooshtari M, Ghadiri Vasfi M. (2017). Definition of Cycle and Episode in Rapid Cycling Bipolar Disorder: An Area of Debate in Diagnosis and Research. Iranian Joumal of Psychiatry and Clinical Psychology, 23(3), pp.254-259. [In Persian]

Spitzer RL, Williams JB, Gibbon M, First MB. (1992). The structured clinical interview for DSM-III$\mathrm{R}$ (SCID): I: history, rationale, and description. Archives of general psychiatry, 49(8), pp.624 629.

Talebi ZM, Shahmir E, Jafari FS. (2013). Effectiveness of Mindfulness-Based Cognitive Therapy in the Decrease of Depression and Maniac 
Symptoms of Individuals Diagnosed with Bipolar Disorder. [n Persian]

Ye BY, Jiang ZY, Li X, Cao B, Cao LP, Lin Y, Xu

GY, Miao GD. (2016). Effectiveness of cognitive behavioral therapy in treating bipolar disorder: A $\mathrm{n}$ updated meta-analysis with randomized controlled trials. Psychiatry and clinical neurosciences, 70(8), pp.351-361.

Young RC, Biggs JT, Ziegler VE, Meyer DA. (1987). A rating scale for mania: reliability, validity and sensitivity. The British joumal of psychiatry, 133(5), pp.429-435.

Zaretsky AE, Segal ZV, Gemar M. (1999). Cognitive therapy for bipolar depression: a pilot study. The Canadian Journal of Psychiatry, 44(5), pp.491-494.

Zhang YS, Rao WW, Zeng LN, Grace KI, Cui LJ, Li JF, Li L, Ungvari GS, Hall BJ, Li KQ, Xiang YT.(2020). Prevalence and correlates of bipolar disorder in the adult population of Hebei province, China. Journal of Affective Disorders, 263, pp.129-133. 